\title{
Association of ALDH1A1 Polymorphism With Toxicity From Cyclophosphamide Treatment
}

\author{
Mary Hwang \\ University of Michigan \\ Sarah Medley \\ University of Michigan School of Public Health \\ Faisal Shakeel \\ University of Michigan \\ Kelley M Kidwell \\ University of Michigan School of Public Health \\ Daniel L Hertz ( $\nabla$ dlhertz@med.umich.edu ) \\ University of Michigan https://orcid.org/0000-0003-0501-1035
}

\section{Research Article}

Keywords: Pharmacogenetic, cyclophosphamide, toxicity, treatment discontinuation, ALDH1A1, CYP2B6

Posted Date: February 8th, 2022

DOI: https://doi.org/10.21203/rs.3.rs-1228933/v1

License: (c) (i) This work is licensed under a Creative Commons Attribution 4.0 International License.

Read Full License 


\section{Abstract}

Purpose: Cyclophosphamide is a commonly used cancer agent that is metabolically activated by polymorphic enzymes. This study aims to investigate the association between genetic polymorphisms of candidate pharmacogenes with severe toxicity during cyclophosphamide treatment.

Methods: Genetic data was collected from an institutional genetic data repository. Genetic polymorphisms in CYP2B6, CYP3A4, CYP2C9, CYP2C19, GSTA1, GSTP1, ALDH1A1, ALDH3A1, ABCC1, $A B C B 1$, and $E R C C 1$ were included in the analysis. Treatment and toxicity data were retrospectively collected from the patient's medical record. The a priori selected primary hypothesis was that patients who have CYP2B6 reduced metabolizer activity (poor or intermediate metabolizer (PM/IM) vs. other) have higher risk of severe toxicity or cyclophosphamide treatment modification due to toxicity.

Results: In the primary analysis of 510 cyclophosphamide-treated patients with available genetic data, there was no difference in the odds of severe toxicity or treatment modification due to toxicity in CYP2B6 $\mathrm{PM} / \mathrm{IM}$ vs. other (Odds ratio=0.97, $95 \%$ Confidence Interval: $0.62-1.50, \mathrm{p}=0.88$ ). In an exploratory, statistically uncorrected secondary analysis, carriers of the $A L D H 1 A 1$ rs8187996 variant had a lower risk of the primary toxicity endpoint compared with wild-type homozygous patients (Odds Ratio $=0.31,95 \%$ Confidence Interval: $0.09-0.78, p=0.028$ ). None of the other tested phenotypes or genotypes were associated with the primary or secondary endpoints in unadjusted analysis (all $p>0.05$ ).

Conclusion: Patients who carry ALDH1A1 rs8187996 may have a lower risk of cyclophosphamide toxicity than wild-type patients. Validation of this associations is necessary to justify development of personalized cyclophosphamide dosing strategies to optimize therapeutic outcomes in patients with cancer.

\section{Introduction}

Cyclophosphamide is a chemotherapy agent used in patients with several tumor types including breast and ovarian cancer and lymphoma. Cyclophosphamide treatment is associated with treatment limiting toxicities including febrile neutropenia and oral mucositis. As a prodrug, cyclophosphamide requires metabolic activation by CYP2B6, CYP3A4, CYP2C9, and CYP2C19 to several intermediate metabolites and its active metabolite, phosphoramide mustard. These intermediate and active metabolites also undergo detoxification by phase II enzymes including GSTP1, ALDH1A1, ALDH3A1.[1, 2]

The field of pharmacogenetics has been particularly successful at finding clinically useful genetic biomarkers for prodrugs,[3] such as clopidogrel and irinotecan. The enzymes involved in cyclophosphamide activation and detoxification have polymorphisms that are known to affect enzyme activity, that may affect systemic concentrations of the active metabolites and treatment-related outcomes. Indeed, several prior studies have reported associations for polymorphisms in the genes encoding these enzymes and in other pharmacogenes relevant to cyclophosphamide pharmacokinetics 
or DNA repair including $A B C B 1, A B C C 1$, and $E R C C 1$.[4-12] In particular, polymorphisms in $C Y P 2 B 6$ have been reported to affect cyclophosphamide pharmacokinetics and toxicity risk. $[5,6,10,12]$

Although potential genetic biomarkers of cyclophosphamide toxicity risk have been reported, none have been consistently replicated across studies. The objective of this study was to investigate the effect of polymorphisms in candidate genes, particularly CYP2B6, with the risk of severe cyclophosphamide toxicity in an independent cohort of cyclophosphamide-treated patients with cancer. Successful replication of these associations could warrant translational studies that personalize cyclophosphamide dosing to optimize therapeutic outcomes in patients with cancer receiving cyclophosphamide treatment.

\section{Methods}

\subsection{Patients and Toxicity Data}

This study was a retrospective pharmacogenetic study of patients with a diagnosis of cancer who were treated with cyclophosphamide as part of their chemotherapy regimen at Michigan Medicine from January 2011 through December 2020. All patients who received at least one cycle of cyclophosphamide for cancer treatment and had available genetic data were included in the study. The study protocol was approved by the Institutional Review Board (IRB\#HUM 00161844).

Clinical data were retrospectively collected from the patients' electronic medical records. The clinical data were collected by an investigator who was blinded to genotype data. Data included individual demographics, cancer type, tumor stage and grade, chemotherapy regimen including dose, frequency, and treatment duration. Toxicity data were collected retrospectively from physician notes for all cyclophosphamide treatment cycles and graded by a blinded investigator based on the Common Terminology Criteria for Adverse Events version 5.0. Only toxicities believed to result from cyclophosphamide were included in the analysis. Treatment modification was defined by any change in the cyclophosphamide treatment including dose discontinuation, reduction, or delay that were attributed to toxicity based on the physician notes.

\subsection{Genotype Data}

Genetic data were obtained from the Michigan Genomics Initiative (MGI) institutional genetic data repository, which conducts genome-wide genotyping and imputation, as previously described.[13, 14$]$ Patients with no genetic data were excluded from the analysis. All genotype calls were obtained for CYP2B6, CYP3A4, CYP2C9, CYP2C19, GSTA1, GSTP1, ALDH1A1, ALDH3A1, ABCC1, ABCB1, and ERCC1. These eleven enzymes and transporters were selected based on prior studies finding an association with cyclophosphamide pharmacokinetics or toxicity.[9-11, 15] Genotype calls were translated into metabolic phenotypes (i.e., ultrarapid (UM), rapid (RM), normal (NM), intermediate (IM), or poor (PM) metabolizer) for each patient for CYP2B6, CYP3A4, CYP2C9, and CYP2C19 via an automated process that uses Stargazer to generate star alleles and metabolic phenotypes that are consistent with recommendations from Clinical Pharmacogenetics Implementation Consortium (CPIC).[16] Patients were then classified into 
two groups for comparison, those with reduced enzyme activity (e.g., PM or IM) and others. For the remaining genes, which do not have consensus systems for star nomenclature or phenotypic activity, patients were categorized as variant carriers if they carried at least one variant and were compared with wild-type homozygous patients. Variant alleles of genes including GSTA1(rs3957357, rs3957356), GSTP1(rs1695), ALDH1A1(rs8187996, rs3764435, rs63319), ALDH3A1(rs2228100), ABCC1(rs903880, rs16967126, rs4148350), $A B C B 1(\mathrm{rs} 1128503, \mathrm{rs} 1045642) E R C C 1(\mathrm{rs} 3212986, \mathrm{rs} 11615)$ were included in this analysis. A composite analysis was conducted for each gene comparing patients who carried at least one of any homozygous or heterozygous variant against patients who were homozygous wild type for all variants in that gene.

\subsection{Statistical analysis}

The primary endpoint was a composite of grade $3+$ toxicity or treatment modification due to the toxicity at any time during cyclophosphamide treatment. Each of the endpoints that composed the composite primary endpoint were analyzed individually as secondary endpoints. The a priori defined primary hypothesis was that $C Y P 2 B 6 \mathrm{PM} / \mathrm{IM}$ patients had a lower rate of grade $3+$ toxicity or treatment modification due to toxicity compared with NM/RM. Secondary analyses were conducted for each of the genes with the primary and secondary endpoints without statistical correction for multiple comparisons. All statistical associations were tested using logistic regression analysis. Significant univariate associations were then adjusted for relevant clinical covariates including age (continuous), race (white vs. other), gender (male vs. female), tumor type (breast cancer vs. other), and chemotherapy regimen (Adriamycin/cyclophosphamides vs. other) in multivariable models. Analyses were conducted in R version 4.0.3.

\section{Results}

\subsection{Patients and Toxicity}

Among the 846 patients who received cyclophosphamide between January 2011 and December 2020, 510 received cyclophosphamide for cancer treatment and had genetic data available and were included in this analysis (Figure 1). The majority of patients were Caucasian (90\%) with a median age of 52.9 years, $86 \%$ were women and the most prevalent diagnosis was breast cancer $(72 \%)$ (Table 1$)$. The primary outcome of grade $3+$ toxicity or treatment modification due to toxicity was recorded in $101(20 \%)$ patients, including $72(14 \%)$ with toxicity and $97(19 \%)$ with treatment modification. The distribution of genetic categories used in the analysis is also reported in Table 1 and the numbers for each metabolic phenotype or polymorphism are reported in Supplementary Table 1.

\subsection{Genetic Association with clinical outcomes}

In the primary analysis, patients with CYP2B6 PM/IM phenotype did not have a lower odds of toxicity or treatment modification than RM/NM (Odds Ratio $(\mathrm{OR})=0.97,95 \%$ Confidence Interval $(95 \% \mathrm{Cl})$ : 0.62-1.50, 
$p=0.88$, Table 2, Figure 2). Similarly, there was no difference in occurrence of either of the secondary toxicity endpoints (both $p>0.05$ ).

Each gene with sufficient genetic variability was included in secondary analyses. There were insufficient patients with CYP3A4 PM/IM phenotype or composite ALDH1A1 wild-type genotype to conduct these analyses (Supplementary Table 1). Patients carrying ALDH1A1 rs8187996 had lower odds of grade 3+ toxicity or treatment modification due to toxicity ( $O R=0.31,95 \% \mathrm{Cl}: 0.09-0.78, p=0.028$, Figure 3 ). This result maintained significance after adjustment (adjusted OR $(a O R)=0.33,95 \% \mathrm{Cl}: 0.10-0.86, p=0.042)$. When separated by secondary endpoint, the association was only with grade $3+$ toxicity $(O R=0.22,95 \%$ Cl: $0.44-0.74, p=0.040, a 0 R=0.23,95 \% \mathrm{Cl}: 0.04-0.78, p=0.047)$, there was no difference in treatment modification due to toxicity ( $p>0.05)$. Due to the low number of patients with homozygous variant genotype $(n=1)$, other genetic models (i.e., additive or dominant) could not be explored. None of the other tested phenotypes or genotypes were associated with the primary or secondary endpoints in unadjusted analysis (all $p>0.05$ ).

\section{Discussion}

Cyclophosphamide is a prodrug metabolized by several enzymes to the toxic metabolite phosphoramide mustard to elicit its therapeutic effect. Polymorphisms in drug-metabolizing enzymes or drug transporters may affect pharmacokinetics of cyclophosphamide or its active metabolites, which could affect treatment efficacy or toxicity. We investigated the effect of polymorphisms in eleven pharmacogenes on cyclophosphamide treatment-related toxicity, with a particular focus on CYP2B6 based on prior evidence of the effect of $C Y P 2 B 6$ polymorphisms on cyclophosphamide pharmacokinetics and toxicity risk. $[5,6$, 10,12 ] Our primary analyses found no evidence of a decrease in toxicity in patients with reduced $C Y P 2 B 6$ activity. In an exploratory, statistically uncorrected secondary analysis, carriers of the ALDH1A1 rs8187996 variant had lower odds of cyclophosphamide toxicity or treatment modification due to toxicity.

A prior pharmacogenetic analysis that reported that patients with breast cancer who carried ALDH1A1 rs8187996 had higher hematological toxicity risk when receiving doxorubicin/cyclophosphamide (AC). [11] This statistically uncorrected secondary analysis of the prospective SWOG 0221 clinical trial was the basis for inclusion of this polymorphism within our analysis. However, our results suggest that carriers of this variant have lower odds of cyclophosphamide toxicity, which is in the opposing direction and should not be considered replication. Aldehyde dehydrogenase (ALDH) enzymes, including ALDH1A1 and ALDH3A1, are responsible for inactivating the intermediate metabolite aldophosphamide to carboxyphosphamide.[15] In silico analyses indicate that $A L D H 1 A 1$ variants could affect aldophosphamide metabolism,[17] however, clinical pharmacokinetics studies have not investigated the effect on aldophosphamide, carboxyphosphamide, or phosphoramide mustard concentrations to our knowledge and no effect has been detected on concentrations of the parent cyclophosphamide compound or the upstream metabolite 4-hydroxycyclophosphamide.[15] The discrepant findings from pharmacogenetic analyses with toxicity, combined with the lack of studies investigating an association 
with concentrations of active cyclophosphamide metabolite concentrations, do not support a clinically useful pharmacogenetic association, though further investigation is warranted.

CYP2B6, CYP2C9, CYP2C19, and CYP3A4 activate cyclophosphamide to 4-hydroxycyclophosphamide. [18] Several prior studies have reported that patients carrying reduced-activity polymorphisms in these drug metabolizing enzymes have lower bioactivation of cyclophosphamide,[5-7] leading to our hypothesis that patients with reduced metabolic activity would have lower risk of cyclophosphamide toxicity. Our study could not identify any effect of CYP2B6 metabolic phenotypes on cyclophosphamideinduced toxicity. A prior study from Tsuji et al. reported that carriers of the reduced-activity $C Y P 2 B 6^{*} 6$ allele had lower risk of severe neutropenia,[10] which is consistent with the reduced cyclophosphamide activation in these patients. $[5,12]$ Our inability to replicate this association may be due to differences in our endpoint, which included all cyclophosphamide toxicity, not just neutropenia. However, retrospective pharmacogenetic analyses of large prospective clinical trials have also been unable to replicate this association.[8] This inconsistent replication suggests that this association, if it is real, can only be identified in certain patient cohorts, potentially based on their cyclophosphamide dose or the other components of their combination chemotherapy regimen. We were also unable to replicate other previously reported associations with cyclophosphamide toxicity for patients who carry variants in other non-CYP pharmacogenes including GSTP1,[8, 9] ERCC1,[10] ABCB1,[4] and ABCC1.[11]

Our results indicate that patients who inherit germline variants in $A L D H 1 A 1$ may have lower risk of cyclophosphamide toxicity. Validation of this association in independent cohorts of cyclophosphamidetreated patients would warrant investigation into cyclophosphamide dose individualization to optimize therapeutic outcomes. Interestingly, ALDH1A1 overexpression has also been implicated in tumor resistance to cyclophosphamide treatment,[19] indicating that germline ALDH1A1 variants may affect both toxicity and efficacy of cyclophosphamide treatment, and both would need to be considered when adjusting treatment.[20] Further work is needed to confirm the effect of $A L D H 1 A 1$ polymorphisms on cyclophosphamide metabolism and treatment outcomes to warrant translational studies that can use this information to optimize clinical outcomes in cyclophosphamide-treated patients.

This study had several limitations that should be considered. First, retrospective collection of toxicity data may contribute to errors in classifying outcome events. Second, this study had a modest small sample size, which may have caused insufficient power to identify some true associations. Also, assuming dominant genetic effects and that all variants in a gene had consistent directions of effect may have prevented identification of some associations. Lastly, we could not demonstrate the mechanisms underlying the putative association between ALDH1A1 rs8187996 and cyclophosphamide toxicity due to the lack of pharmacokinetic data for these patients.

In conclusion, patients who carry ALDH1A1 rs8187996 may have lower risk of cyclophosphamideinduced toxicity. Confirmation of this associations in independent cohorts of cyclophosphamide-treated patients is necessary to justify translational studies evaluating the effect of genotype-guided 
cyclophosphamide dosing on treatment toxicity and efficacy, which may optimize therapeutic outcomes in patients with cancer.

\section{Declarations}

\section{Funding}

No funding was used for this work.

\section{Conflicts of Interest/Competing Interests}

The authors have no relevant financial or non-financial interests to disclose.

\section{Availability of data and material}

Data will be made available upon reasonable request to the corresponding author

\section{Code Availability}

Code will be made available upon reasonable request to the corresponding author

\section{Authors' Contributions}

Conceptualization: Daniel Hertz and Faisal Shakeel; Methodology: Mary Hwang, Faisal Shakeel, Kelley Kidwell and Daniel Hertz; Formal analysis and investigation: Sarah Medley and Kelley Kidwell; Writing original draft preparation: Mary Hwang; Writing - review and editing: Sarah Medley and Daniel Hertz; Supervision: Daniel Hertz and Kelley Kidwell.

All authors read and approved the final manuscript.

\section{Ethics Approval}

This study protocol was approved by the Institutional Review Board (IRB\#HUM 00161844) at the University of Michigan.

\section{Consent to participate}

All patients agreed to participate in the Michigan Genomics Initiative, including permission to use their genetic and healthcare data for genetic analyses.

\section{Consent for publication}

No individual data or images are included in this publication.

\section{Acknowledgements}


The authors acknowledge the Michigan Genomics Initiative participants, Precision Health at the University of Michigan, the University of Michigan Medical School Central Biorepository, and the University of Michigan Advanced Genomics Core for providing data and specimen storage, management, processing, and distribution services, and the Center for Statistical Genetics in the Department of Biostatistics at the School of Public Health for genotype data curation, imputation, and management in support of the research reported in this publication/grant application/presentation.

\section{References}

1. Dirven HA, van Ommen B, van Bladeren PJ. Involvement of human glutathione S-transferase isoenzymes in the conjugation of cyclophosphamide metabolites with glutathione. Cancer Res. 1994;54(23):6215-20.

2. Sládek NE. Aldehyde dehydrogenase-mediated cellular relative insensitivity to the oxazaphosphorines. Curr Pharm Des. 1999;5(8):607-25.

3. Begg EJ, Helsby NA, Jensen BP. Pharmacogenetics of drug-metabolizing enzymes: the prodrug hypothesis. Pharmacogenomics. 2012;13(1):83-9. doi: 10.2217/pgs.11.134; 10.2217/pgs.11.134.

4. Ikeda M, Tsuji D, Yamamoto K, Kim YI, Daimon T, Iwabe Y, et al. Relationship between ABCB1 gene polymorphisms and severe neutropenia in patients with breast cancer treated with doxorubicin/cyclophosphamide chemotherapy. Drug Metab Pharmacokinet. 2015;30(2):149-53. doi: 10.1016/j.dmpk.2014.09.009. Epub Nov 4.

5. Helsby NA, Hui CY, Goldthorpe MA, Coller JK, Soh MC, Gow PJ, et al. The combined impact of CYP2C19 and CYP2B6 pharmacogenetics on cyclophosphamide bioactivation. Br J Clin Pharmacol. 2010;70(6):844-53. doi: 10.1111/j.365-2125.010.03789.x.

6. Helsby N, Yong M, Burns K, Findlay M, Porter D. Cyclophosphamide bioactivation pharmacogenetics in breast cancer patients. Cancer Chemother Pharmacol. 2021;88(3):533-42. doi: 10.1007/s00280021-4307-0. Epub 2021 Jun 10.

7. Timm R, Kaiser R, Lotsch J, Heider U, Sezer O, Weisz K, et al. Association of cyclophosphamide pharmacokinetics to polymorphic cytochrome P450 2C19. Pharmacogenomics J. 2005;5(6):365-73.

8. Yao S, Barlow WE, Albain KS, Choi JY, Zhao H, Livingston RB, et al. Gene polymorphisms in cyclophosphamide metabolism pathway,treatment-related toxicity, and disease-free survival in SWOG 8897 clinical trial for breast cancer. Clin Cancer Res. 2010;16(24):6169-76. doi: 10.1158/0780432.CCR-10-281.

9. Zhang BL, Sun T, Zhang BN, Zheng S, Lü N, Xu BH, et al. Polymorphisms of GSTP1 is associated with differences of chemotherapy response and toxicity in breast cancer. Chin Med J (Engl). 2011;124(2):199-204.

10. Tsuji D, Ikeda M, Yamamoto K, Nakamori H, Kim Yl, Kawasaki Y, et al. Drug-related genetic polymorphisms affecting severe chemotherapy-induced neutropenia in breast cancer patients: A hospital-based observational study. Medicine (Baltimore). 2016;95(44):e5151. doi:

10.1097/MD.0000000000005151. 
11. Yao S, Sucheston LE, Zhao H, Barlow WE, Zirpoli G, Liu S, et al. Germline genetic variants in ABCB1, $A B C C 1$ and $A L D H 1 A 1$, and risk of hematological and gastrointestinal toxicities in a SWOG Phase III trial S0221 for breast cancer. Pharmacogenomics J. 2014;14(3):241-7. doi: 10.1038/tpj.2013.32. Epub Sep 3.

12. Nakajima M, Komagata S, Fujiki Y, Kanada Y, Ebi H, Itoh K, et al. Genetic polymorphisms of CYP2B6 affect the pharmacokinetics/pharmacodynamics of cyclophosphamide in Japanese cancer patients. Pharmacogenetics \& Genomics. 2007;17(6):431-45.

13. Fritsche LG, Gruber SB, Wu Z, Schmidt EM, Zawistowski M, Moser SE, et al. Association of Polygenic Risk Scores for Multiple Cancers in a Phenome-wide Study: Results from The Michigan Genomics Initiative. Am J Hum Genet. 2018;102(6):1048-61. doi: 10.16/j.ajhg.2018.04.001. Epub May 17.

14. Shakeel F, Fang F, Kwon JW, Koo K, Pasternak AL, Henry NL, et al. Patients carrying DPYD variant alleles have increased risk of severe toxicity and related treatment modifications during fluoropyrimidine chemotherapy. Pharmacogenomics. 2021;22(3):145-55. doi: 10.2217/pgs-0200154. Epub 2021 Jan 7.

15. Ekhart C, Doodeman VD, Rodenhuis S, Smits PH, Beijnen JH, Huitema AD. Influence of polymorphisms of drug metabolizing enzymes (CYP2B6, CYP2C9, CYP2C19, CYP3A4, CYP3A5, GSTA1, GSTP1, ALDH1A1 and ALDH3A1) on the pharmacokinetics of cyclophosphamide and 4hydroxycyclophosphamide. Pharmacogenet Genomics. 2008;18(6):515-23. doi: 10.1097/FPC.0b013e3282fc9766.

16. Lee SB, Wheeler MM, Patterson K, McGee S, Dalton R, Woodahl EL, et al. Stargazer: a software tool for calling star alleles from next-generation sequencing data using CYP2D6 as a model. Genet Med. 2019;21(2):361-72. doi: 10.1038/s41436-018-0054-0. Epub 2018 Jun 6.

17. Verma H, Silakari O. Investigating the Role of Missense SNPs on ALDH 1 A1 mediated pharmacokinetic resistance to cyclophosphamide. Comput Biol Med. 2020;125:103979. (doi):10.1016/j.compbiomed.2020.103979. Epub 2020 Aug 24.

18. Roy P, Yu LJ, Crespi CL, Waxman DJ. Development of a substrate-activity based approach to identify the major human liver P-450 catalysts of cyclophosphamide and ifosfamide activation based on cDNA-expressed activities and liver microsomal P-450 profiles. Drug Metab Dispos. 1999;27(6):65566.

19. Narendra G, Raju B, Verma H, Silakari O. Identification of potential genes associated with ALDH1A1 overexpression and cyclophosphamide resistance in chronic myelogenous leukemia using network analysis. Med Oncol. 2021;38(10):123. doi: 10.1007/s12032-021-01569-9.

20. Hertz DL, Ramsey LB, Gopalakrishnan M, Leeder JS, Van Driest SL. Analysis Approaches to Identify Pharmacogenetic Associations with Pharmacodynamics. Clin Pharmacol Ther. 2021;27(10).

\section{Tables}




\begin{tabular}{|c|c|c|}
\hline & & $\begin{array}{l}N(\%) \text { or mean (standard } \\
\text { deviation) } \\
(n=510)\end{array}$ \\
\hline Age & Years & $52.86(13.19)$ \\
\hline \multirow[t]{2}{*}{ Race } & Caucasian & $460(90 \%)$ \\
\hline & Other/unknown & $50(9.8 \%)$ \\
\hline \multirow[t]{2}{*}{ Gender } & Female & $439(86 \%)$ \\
\hline & Male & $71(14 \%)$ \\
\hline \multirow[t]{2}{*}{ Primary site of cancer } & Breast & 368 (72\%) \\
\hline & Other & $142(28 \%)$ \\
\hline \multirow[t]{2}{*}{ Treatment regimen } & $A C$, (including AC-T) & $228(45 \%)$ \\
\hline & Other & $282(55 \%)$ \\
\hline \multirow{3}{*}{$\begin{array}{l}\text { Cyclophosphamide } \\
\text { Toxicity }\end{array}$} & Grade $3+$ or treatment modification & $101(20 \%)$ \\
\hline & Grade 3+ & $72(14 \%)$ \\
\hline & $\begin{array}{l}\text { Treatment modification due to } \\
\text { toxicity }\end{array}$ & $97(19 \%)$ \\
\hline \multirow[t]{2}{*}{ CYP2B6 Phenotype } & $\mathrm{PM} / \mathrm{IM}$ & $215(42.5 \%)$ \\
\hline & Other & $295(58.4 \%)$ \\
\hline \multirow[t]{2}{*}{ CYP2C9 Phenotype } & $\mathrm{PM} / \mathrm{IM}$ & $179(35.4 \%)$ \\
\hline & Other & $331(65 \%)$ \\
\hline \multirow[t]{2}{*}{ CYP2C19 Phenotype } & $\mathrm{PM} / \mathrm{IM}$ & $154(30.3 \%)$ \\
\hline & Other & $356(69.1 \%)$ \\
\hline \multirow[t]{2}{*}{ GSTA1 } & Wild type & $83(16 \%)$ \\
\hline & Variant carriers & $427(84 \%)$ \\
\hline \multirow[t]{2}{*}{ GSTP1 } & Wild type & $226(44 \%)$ \\
\hline & Variant carriers & $284(56 \%)$ \\
\hline \multirow[t]{2}{*}{ ALDH1A1 rs8187996 } & Wild type & $458(90 \%)$ \\
\hline & Variant carriers & $52(10.2 \%)$ \\
\hline ALDH1A1 rs3764435 & Wild type & $132(26 \%)$ \\
\hline
\end{tabular}




\begin{tabular}{|c|c|c|}
\hline & & $\begin{array}{l}N(\%) \text { or mean (standard } \\
\text { deviation) } \\
(n=510)\end{array}$ \\
\hline & Variant carriers & 378 (74\%) \\
\hline \multirow[t]{2}{*}{ ALDH1A1 rs63319 } & Wild type & $118(23 \%)$ \\
\hline & Variant carriers & 392 (77\%) \\
\hline \multirow[t]{2}{*}{ ALDH3A1 } & Wild type & 277 (54\%) \\
\hline & Variant carriers & 233 (46\%) \\
\hline \multirow[t]{2}{*}{$\mathrm{ABCC} 1$} & Wild type & $259(51 \%)$ \\
\hline & Variant carriers & $251(49 \%)$ \\
\hline \multirow[t]{2}{*}{ ABCB1 } & Wild type & $84(16 \%)$ \\
\hline & Variant carriers & $426(84 \%)$ \\
\hline \multirow[t]{2}{*}{ ERCC1 } & Wild type & $173(34 \%)$ \\
\hline & Variant carriers & $337(66 \%)$ \\
\hline
\end{tabular}


Table 2

Genetic Associations with Toxicity from Cyclophosphamide Treatment

\begin{tabular}{|c|c|c|c|c|c|c|c|}
\hline \multirow[b]{2}{*}{ Gene or SNP } & \multirow[b]{2}{*}{ Comparison } & \multicolumn{2}{|c|}{$\begin{array}{l}\text { Grade 3+ Toxicity or } \\
\text { Treatment } \\
\text { Modification }\end{array}$} & \multicolumn{2}{|c|}{ Grade 3+ Toxicity } & \multicolumn{2}{|c|}{$\begin{array}{l}\text { Treatment } \\
\text { Modification } \\
\text { due to Toxicity }\end{array}$} \\
\hline & & OR $(95 \% \mathrm{Cl})$ & $\begin{array}{l}\mathrm{p}- \\
\text { value }\end{array}$ & $\begin{array}{l}\text { OR }(95 \% \\
\mathrm{Cl})\end{array}$ & $\begin{array}{l}\mathrm{p}- \\
\text { value }\end{array}$ & $\begin{array}{l}\text { OR }(95 \% \\
\mathrm{Cl})\end{array}$ & $\begin{array}{l}\mathrm{p}- \\
\text { value }\end{array}$ \\
\hline CYP2B6 & $\begin{array}{l}\mathrm{PM} / \mathrm{IM} \text { vs. } \\
\text { other }\end{array}$ & $\begin{array}{l}0.97(0.62- \\
1.50) *\end{array}$ & 0.88 & $\begin{array}{l}1.11(0.67- \\
1.84)\end{array}$ & 0.67 & $\begin{array}{l}0.73 \\
(0.43- \\
1.22)\end{array}$ & 0.24 \\
\hline CYP2C9 & $\begin{array}{l}\mathrm{PM} / \mathrm{IM} \text { vs. } \\
\text { other }\end{array}$ & $\begin{array}{l}1.15(0.73- \\
1.81)\end{array}$ & 0.53 & $\begin{array}{l}1.21(0.72- \\
2.01)\end{array}$ & 0.47 & $\begin{array}{l}0.90 \\
(0.52- \\
1.52)\end{array}$ & 0.69 \\
\hline CYP2C19 & $\begin{array}{l}\mathrm{PM} / \mathrm{IM} \text { vs. } \\
\text { other }\end{array}$ & $\begin{array}{l}0.97(0.59- \\
1.55)\end{array}$ & 0.89 & $\begin{array}{l}1.02(0.58- \\
1.73)\end{array}$ & 0.94 & $\begin{array}{l}0.84 \\
(0.47- \\
1.45)\end{array}$ & 0.54 \\
\hline GSTA1 & $\begin{array}{l}\text { Variant vs } \\
\text { WT }\end{array}$ & $\begin{array}{l}1.26(0.70- \\
2.44)\end{array}$ & 0.46 & $\begin{array}{l}1.24(0.63- \\
2.67)\end{array}$ & 0.55 & $\begin{array}{l}1.60 \\
(0.77- \\
3.74)\end{array}$ & 0.24 \\
\hline $\begin{array}{l}\text { GSTA1 } \\
\text { rs3957357 }\end{array}$ & $\begin{array}{l}\text { Variant vs } \\
\text { WT }\end{array}$ & $\begin{array}{l}1.26(0.70- \\
2.44)\end{array}$ & 0.46 & $\begin{array}{l}1.24(0.63- \\
2.67)\end{array}$ & 0.55 & $\begin{array}{l}1.60 \\
(0.77- \\
3.74)\end{array}$ & 0.24 \\
\hline $\begin{array}{l}\text { GSTA1 } \\
\text { rs3957356 }\end{array}$ & $\begin{array}{l}\text { Variant vs } \\
\text { WT }\end{array}$ & $\begin{array}{l}1.26(0.70- \\
2.44)\end{array}$ & 0.46 & $\begin{array}{l}1.24(0.63- \\
2.67)\end{array}$ & 0.55 & $\begin{array}{l}1.60 \\
(0.77- \\
3.74)\end{array}$ & 0.24 \\
\hline GSTP1 rs1695 & $\begin{array}{l}\text { Variant vs } \\
\text { WT }\end{array}$ & $\begin{array}{l}1.09(0.70- \\
1.69)\end{array}$ & 0.71 & $\begin{array}{l}1.39(0.84- \\
2.34)\end{array}$ & 0.21 & $\begin{array}{l}0.82 \\
(0.49- \\
1.36)\end{array}$ & 0.43 \\
\hline $\begin{array}{l}\text { ALDH1A1 } \\
\text { rs8187996 }\end{array}$ & $\begin{array}{l}\text { Variant vs } \\
\text { WT }\end{array}$ & $\begin{array}{l}0.31(0.09- \\
0.78)\end{array}$ & 0.028 & $\begin{array}{l}0.22(0.04- \\
0.74)\end{array}$ & 0.040 & $\begin{array}{l}0.49 \\
(0.15- \\
1.26)\end{array}$ & 0.19 \\
\hline $\begin{array}{l}\text { ALDH1A1 } \\
\text { rs3764435 }\end{array}$ & $\begin{array}{l}\text { Variant vs } \\
\text { WT }\end{array}$ & $\begin{array}{l}1.42(0.85- \\
2.46)\end{array}$ & 0.19 & $\begin{array}{l}1.53(0.84- \\
2.94)\end{array}$ & 0.18 & $\begin{array}{l}1.33 \\
(0.74- \\
2.53)\end{array}$ & 0.36 \\
\hline $\begin{array}{l}\text { ALDH1A1 } \\
\text { rs63319 }\end{array}$ & $\begin{array}{l}\text { Variant vs } \\
\text { WT }\end{array}$ & $\begin{array}{l}0.79(0.48- \\
1.31)\end{array}$ & 0.35 & $\begin{array}{l}0.81(0.47- \\
1.47)\end{array}$ & 0.48 & $\begin{array}{l}0.78 \\
(0.45- \\
1.41)\end{array}$ & 0.40 \\
\hline $\begin{array}{l}\text { ALDH3A1 } \\
\text { rs2228100 }\end{array}$ & $\begin{array}{l}\text { Variant vs } \\
\text { WT }\end{array}$ & $\begin{array}{l}1.09(0.70- \\
1.69)\end{array}$ & 0.69 & $\begin{array}{l}0.83(0.50- \\
1.37)\end{array}$ & 0.46 & $\begin{array}{l}1.49 \\
(0.90- \\
2.48)\end{array}$ & 0.13 \\
\hline
\end{tabular}




\begin{tabular}{|c|c|c|c|c|c|c|c|}
\hline \multirow[b]{2}{*}{$\mathrm{ABCC} 1$} & \multirow[b]{2}{*}{$\begin{array}{l}\text { Variant vs } \\
\text { WT }\end{array}$} & \multicolumn{2}{|c|}{$\begin{array}{l}\text { Grade } 3+\text { Toxicity or } \\
\text { Treatment } \\
\text { Modification }\end{array}$} & \multicolumn{2}{|c|}{ Grade 3+ Toxicity } & \multicolumn{2}{|c|}{$\begin{array}{l}\text { Treatment } \\
\text { Modification } \\
\text { due to Toxicity }\end{array}$} \\
\hline & & $\begin{array}{l}0.87(0.56- \\
1.35)\end{array}$ & 0.53 & $\begin{array}{l}0.97(0.59- \\
1.60)\end{array}$ & 0.91 & $\begin{array}{l}0.85 \\
(0.51- \\
1.40)\end{array}$ & 0.52 \\
\hline $\begin{array}{l}\text { ABCC1 } \\
\text { rs903880 }\end{array}$ & $\begin{array}{l}\text { Variant vs } \\
\text { WT }\end{array}$ & $\begin{array}{l}0.83(0.53- \\
1.29)\end{array}$ & 0.41 & $\begin{array}{l}0.87(0.52- \\
1.44)\end{array}$ & 0.60 & $\begin{array}{l}0.86 \\
(0.51- \\
1.43)\end{array}$ & 0.56 \\
\hline $\begin{array}{l}\text { ABCC1 } \\
\text { rs16967126 }\end{array}$ & $\begin{array}{l}\text { Variant vs } \\
\text { WT }\end{array}$ & $\begin{array}{l}1.08(0.61- \\
1.84)\end{array}$ & 0.79 & $\begin{array}{l}0.94(0.48- \\
1.75)\end{array}$ & 0.86 & $\begin{array}{l}0.87 \\
(0.43- \\
1.65)\end{array}$ & 0.69 \\
\hline $\begin{array}{l}\text { ABCC1 } \\
\text { rs4148350 }\end{array}$ & $\begin{array}{l}\text { Variant vs } \\
\text { WT }\end{array}$ & $\begin{array}{l}1.78(0.93- \\
3.28)\end{array}$ & 0.07 & $\begin{array}{l}1.84(0.88- \\
3.59)\end{array}$ & 0.09 & $\begin{array}{l}1.67 \\
(0.78- \\
3.38)\end{array}$ & 0.16 \\
\hline ABCB1 & $\begin{array}{l}\text { Variant vs } \\
\text { WT }\end{array}$ & $\begin{array}{l}1.43(0.78- \\
2.80)\end{array}$ & 0.27 & $\begin{array}{l}1.26(0.64- \\
2.71)\end{array}$ & 0.52 & $\begin{array}{l}1.22 \\
(0.62- \\
2.62)\end{array}$ & 0.59 \\
\hline $\begin{array}{l}\text { ABCB1 } \\
\text { rs1128503 }\end{array}$ & $\begin{array}{l}\text { Variant vs } \\
\text { WT }\end{array}$ & $\begin{array}{l}1.16(0.67- \\
2.09)\end{array}$ & 0.61 & $\begin{array}{l}1.26(0.67- \\
2.54)\end{array}$ & 0.50 & $\begin{array}{l}1.08 \\
(0.58- \\
2.15)\end{array}$ & 0.81 \\
\hline $\begin{array}{l}\text { ABCB1 } \\
\text { rs1045642 }\end{array}$ & $\begin{array}{l}\text { Variant vs } \\
\text { WT }\end{array}$ & $\begin{array}{l}1.65(0.98- \\
2.88)\end{array}$ & 0.07 & $\begin{array}{l}1.48(0.83- \\
2.81)\end{array}$ & 0.20 & $\begin{array}{l}1.57 \\
(0.87- \\
3.04)\end{array}$ & 0.15 \\
\hline ERCC1 & $\begin{array}{l}\text { Variant vs } \\
\text { WT }\end{array}$ & $\begin{array}{l}1.01(0.64- \\
1.61)\end{array}$ & 0.98 & $\begin{array}{l}0.68(0.64- \\
1.61)\end{array}$ & 0.14 & $\begin{array}{l}1.32 \\
(0.77- \\
2.35)\end{array}$ & 0.32 \\
\hline $\begin{array}{l}\text { ERCC1 } \\
\text { rs3212986 }\end{array}$ & $\begin{array}{l}\text { Variant vs } \\
\text { WT }\end{array}$ & $\begin{array}{l}1.25(0.81- \\
1.94)\end{array}$ & 0.31 & $\begin{array}{l}0.90(0.54- \\
1.48)\end{array}$ & 0.68 & $\begin{array}{l}1.24 \\
(0.74- \\
2.05)\end{array}$ & 0.41 \\
\hline $\begin{array}{l}\text { ERCC1 } \\
\text { rs11615 }\end{array}$ & $\begin{array}{l}\text { Variant vs } \\
\text { WT }\end{array}$ & $\begin{array}{l}0.95(0.61- \\
1.51)\end{array}$ & 0.84 & $\begin{array}{l}0.63(0.38- \\
1.04)\end{array}$ & 0.07 & $\begin{array}{l}1.29 \\
(0.75- \\
2.26)\end{array}$ & 0.37 \\
\hline
\end{tabular}

\section{Supplementary Table}

\section{Supplementary Table 1}




\begin{tabular}{|c|c|c|}
\hline \multirow[t]{5}{*}{ CYP2B6 phenotype } & Rapid metabolizer & $5(1.0 \%)$ \\
\hline & Normal metabolizer & $278(55 \%)$ \\
\hline & Intermediate metabolizer & $182(36 \%)$ \\
\hline & Poor metabolizer & $33(6.5 \%)$ \\
\hline & Indeterminate & $12(2.4 \%)$ \\
\hline \multirow[t]{3}{*}{ CYP3A4 phenotype } & Normal metabolizer & $456(89 \%)$ \\
\hline & Intermediate metabolizer & $1(0.2 \%)$ \\
\hline & Unknown metabolizer & $53(10 \%)$ \\
\hline \multirow[t]{3}{*}{ CYP2C9 phenotype } & Normal metabolizer & $331(65 \%)$ \\
\hline & Intermediate metabolizer & $167(33 \%)$ \\
\hline & Poor metabolizer & $12(2.4 \%)$ \\
\hline \multirow[t]{6}{*}{ CYP2C19 phenotype } & Ultrarapid metabolizer & $26(5.1 \%)$ \\
\hline & Rapid metabolizer & $134(26 \%)$ \\
\hline & Normal metabolizer & $196(38 \%)$ \\
\hline & Intermediate metabolizer & $132(26 \%)$ \\
\hline & Likely intermediate metabolizer & $1(0.2 \%)$ \\
\hline & Poor metabolizer & $21(4.1 \%)$ \\
\hline \multirow[t]{2}{*}{ GSTA1 Composite } & Wild type & $83(16 \%)$ \\
\hline & Variant carriers & $427(84 \%)$ \\
\hline \multirow[t]{3}{*}{ GSTA1 rs3957357 } & Wild type (AA) & $83(16 \%)$ \\
\hline & Heterozygous variant (AG) & $251(49 \%)$ \\
\hline & Homozygous variant (GG) & $176(35 \%)$ \\
\hline \multirow[t]{3}{*}{ GSTA1 rs3957356 } & Wild type (TT) & $83(16 \%)$ \\
\hline & Heterozygous variant (TC) & $251(49 \%)$ \\
\hline & Homozygous variant (CC) & $176(35 \%)$ \\
\hline \multirow[t]{2}{*}{ GSTP1 Composite } & Wild type & $226(44 \%)$ \\
\hline & Variant carriers & $284(56 \%)$ \\
\hline \multirow[t]{2}{*}{ GSTP1 rs1695 } & Wild type (AA) & $226(44 \%)$ \\
\hline & Heterozygous variant (AG) & $227(45 \%)$ \\
\hline
\end{tabular}




\begin{tabular}{|c|c|c|}
\hline & Homozygous variant (GG) & $57(11 \%)$ \\
\hline \multirow[t]{2}{*}{ ALDH1A1 Composite } & Wild type & $5(1 \%)$ \\
\hline & Variant carriers & 505 (99\%) \\
\hline \multirow[t]{3}{*}{ ALDH1A1 rs8187996 } & Wild type (CC) & $458(90 \%)$ \\
\hline & Heterozygous variant (CT) & $51(10 \%)$ \\
\hline & Homozygous variant (TT) & $1(0.2 \%)$ \\
\hline \multirow[t]{3}{*}{ ALDH1A1 rs3764435 } & Wild type (AA) & $132(26 \%)$ \\
\hline & Heterozygous variant (AC) & $277(54 \%)$ \\
\hline & Homozygous variant (CC) & $101(20 \%)$ \\
\hline \multirow[t]{3}{*}{ ALDH1A1 rs63319 } & Wild type (GG) & $118(23 \%)$ \\
\hline & Heterozygous variant (GT) & $258(51 \%)$ \\
\hline & Homozygous variant (TT) & 134 (26\%) \\
\hline \multirow[t]{2}{*}{ ALDH3A1 Composite } & Wild type & 277 (54\%) \\
\hline & Variant carriers & $233(46 \%)$ \\
\hline \multirow[t]{3}{*}{ ALDH3A1 rs2228100 } & Wild type (GG) & 277 (54\%) \\
\hline & Heterozygous variant (GC) & 199 (39\%) \\
\hline & Homozygous variant (CC) & $34(7 \%)$ \\
\hline \multirow[t]{2}{*}{ ABCC1 Composite } & Wild type & $259(51 \%)$ \\
\hline & Variant carriers & $251(49 \%)$ \\
\hline \multirow[t]{3}{*}{ ABCC1 rs903880 } & Wild type (CC) & $290(57 \%)$ \\
\hline & Heterozygous variant (CA) & 175 (34\%) \\
\hline & Homozygous variant (AA) & 45 (9\%) \\
\hline \multirow[t]{3}{*}{ ABCC1 rs16967126 } & Wild type (TT) & $414(81 \%)$ \\
\hline & Heterozygous variant (TC) & $91(18 \%)$ \\
\hline & Homozygous variant (CC) & $5(1 \%)$ \\
\hline \multirow[t]{3}{*}{ ABCC1 rs4148350 } & Wild type (GG) & 455 (89\%) \\
\hline & Heterozygous variant (GT) & $51(10 \%)$ \\
\hline & Homozygous variant (TT) & $4(1 \%)$ \\
\hline ABCB1 Composite & Wild type & $84(16 \%)$ \\
\hline
\end{tabular}




\begin{tabular}{|c|c|c|}
\hline & Variant carriers & $426(84 \%)$ \\
\hline \multirow[t]{3}{*}{ ABCB1 rs1128503 } & Wild type (AA) & $100(20 \%)$ \\
\hline & Heterozygous variant ( $A G$ ) & $231(45 \%)$ \\
\hline & Homozygous variant (GG) & 179 (35\%) \\
\hline \multirow[t]{3}{*}{ ABCB1 rs1045642 } & Wild type (AA) & $138(27 \%)$ \\
\hline & Heterozygous variant (AG) & $247(48 \%)$ \\
\hline & Homozygous variant (GG) & $125(25 \%)$ \\
\hline \multirow[t]{2}{*}{ ERCC1 Composite } & Wild type & $173(34 \%)$ \\
\hline & Variant carriers & 337 (66\%) \\
\hline \multirow[t]{3}{*}{ ERCC1 rs3212986 } & Wild type (CC) & $286(56 \%)$ \\
\hline & Heterozygous variant (CA) & $181(35 \%)$ \\
\hline & Homozygous variant (AA) & $43(8 \%)$ \\
\hline \multirow[t]{3}{*}{ ERCC1 rs11615 } & Wild type (AA) & 178 (35\%) \\
\hline & Heterozygous variant (AG) & $228(45 \%)$ \\
\hline & Homozygous variant (GG) & $104(20 \%)$ \\
\hline
\end{tabular}

\section{Figures}




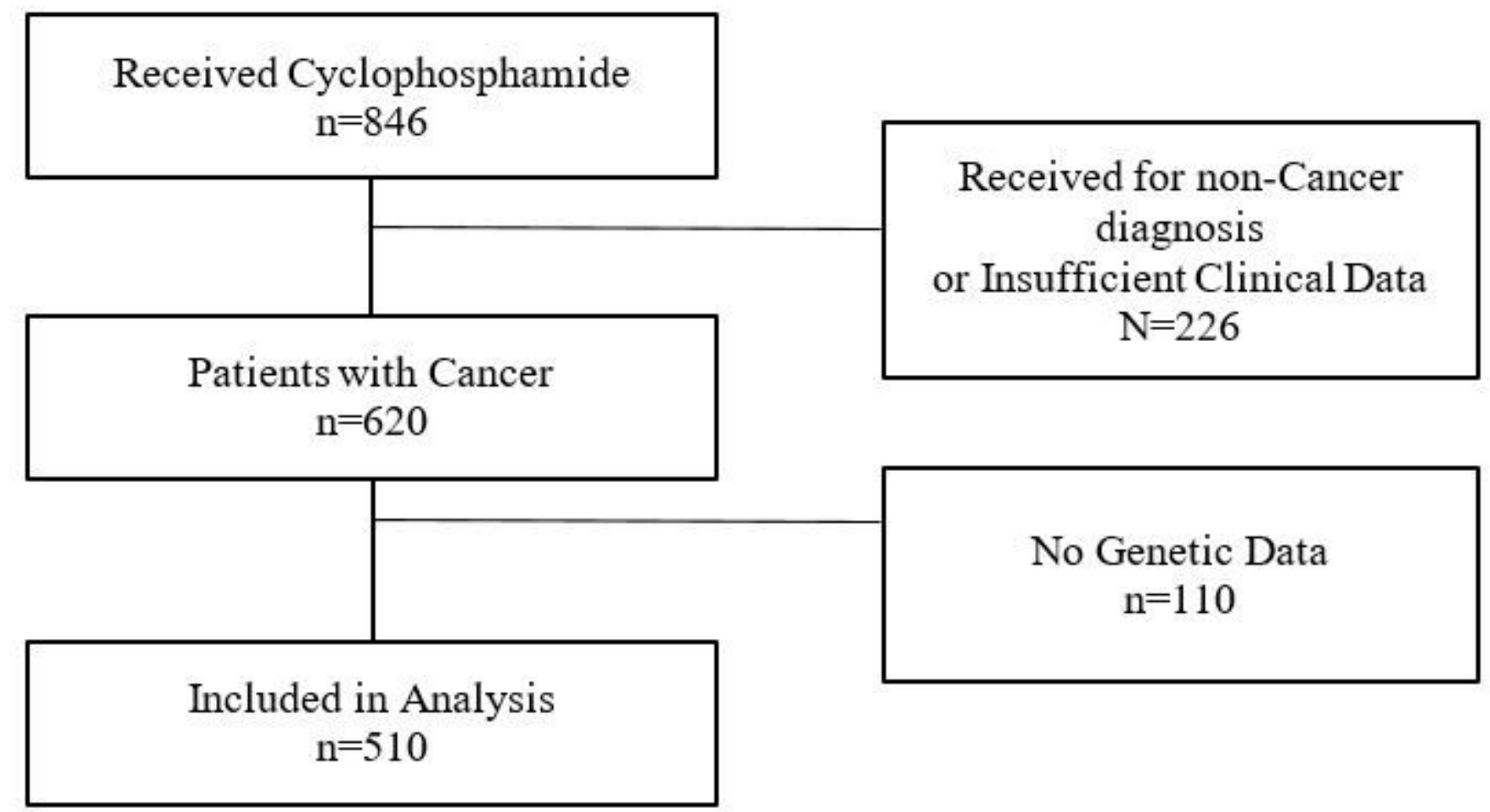

Figure 1

Patient Identification and Inclusion in the Analysis.

Figure 2

Risk of Toxicity or Treatment Modification by CYP2B6 Phenotype. There was no difference in occurrence of grade $3+$ toxicity or treatment modification due to toxicity in CYP2B6 PM/IM compared to RM/NM in the primary analysis (Odds ratio $=0.97,95 \%$ Confidence Interval: $0.62-1.50, p=0.88$ ). 


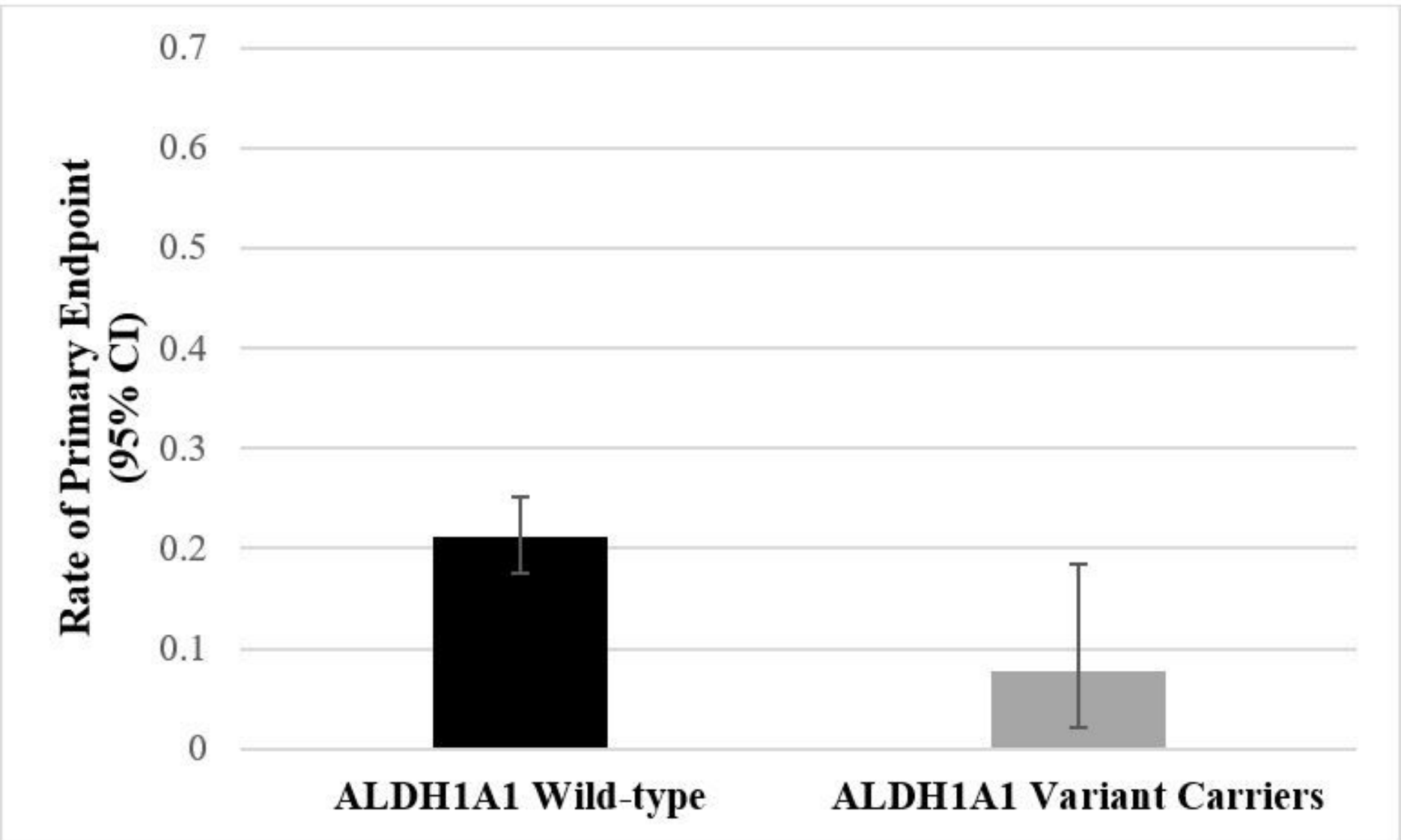

Figure 3

Risk of Toxicity or Treatment Modification by ALDH1A1 rs8187996. Patients carrying rs8187996 variant alleles had lower odds of grade $3+$ toxicity or treatment modification due to toxicity compared to wildtype homozygous patients (Odds Ratio=0.31, 95\% Confidence Interval: 0.09-0.78, $p=0.028$ ). 